\title{
A Backdoor to Policy Making: The Use of Philosophers by the Supreme Court
}

\author{
Neomi Rao $\dagger$
}

The Supreme Court's decisions in Vacco $v$ Quill ${ }^{1}$ and Washington $v$ Glucksberg ${ }^{2}$ held that a state can ban assisted suicide without violating the Due Process or Equal Protection Clauses of the Fourteenth Amendment. In these high profile cases, six philosophers filed an amicus brief ("Philosophers' Brief") that argued for the recognition of a constitutional right to die. ${ }^{3}$ Although the brief was written by six of the most prominent American philosophers-Ronald Dworkin, Thomas Nagel, Robert Nozick, John Rawls, Thomas Scanlon, and Judith Jarvis Thomson-the Court made no mention of the brief in unanimously reaching the opposite conclusion. ${ }^{4}$

In light of the Court's recent failure to engage philosophical arguments, this Comment examines the conditions under which philosophy does and should affect judicial decision making. These questions are relevant in considering the proper role of the Court in controversial political questions and are central to a recent debate focusing on whether the law can still be considered an autonomous discipline that relies only on traditional legal sources. Scholars concerned with law and economics and critical legal studies have argued that the law is no longer autonomous, but rather that it does and should draw on many external sources in order to resolve legal disputes. Critics of this view have maintained that legal reasoning is distinct from other disciplines, and that the law has and should maintain its own methods, conventions, and conclusions.

This Comment follows the latter group of scholars, and argues that the Court should, as it did in the right-to-die cases, stay clear of philosophy and base its decisions on history, precedent, and a recognition of the limits of judicial authority. Three major

$\dagger$ B.A. 1995, Yale University; J.D. Candidate 1999, The University of Chicago.

117 S Ct 2293, 2296 (1997).

117 S Ct 2258, 2261 (1997).

3 Brief for Ronald Dworkin, et al, as Amici Curiae in support of Respondents, Glucksberg, 117 S Ct 2258, available at 1996 WL 708956 ("Philosophers' Brief").

- In addition to the brief itself, Dworkin, a professor of both law and philosophy, wrote a lengthy piece justifying the position taken in the brief. Ronald Dworkin, Assisted Suicide: The Philosophers' Brief, NY Rev of Books 41 (Mar 27, 1997). 
distinctions between the philosophical and the judicial enterprises compel this conclusion. First, judicial decision making is a practical activity, involving actual disputes and having real political consequences. Philosophers focus more on theory, concepts, and abstractions. Second, judges must work within institutional constraints in a political system that requires separation of powers. Philosophers need not consider institutional boundaries; thus, they are free to argue what they choose. Finally, judges in the Anglo-American legal system are bound by legal precedent, and draw legitimacy from references to cultural and political history. Philosophers are not so bound by history and precedent. This Comment concludes that philosophy and judicial decision making are two very different enterprises, and, accordingly, that the Court's recent trend toward using more philosophers should be viewed with caution, at least insofar as philosophers are used as a means for the Court to reach decisions better left to the political process.

Part I provides an empirical study of all the cases-fewer than fifty-in which the Court has cited philosophers. This survey reveals a dramatic increase in the use of philosophical references by the Court in the past thirty years, often in highly controversial cases regarding such issues as abortion and sexual ethics. Part II compares the right-to-die cases with the Philosophers' Brief. It shows how the Court's focus on history and precedent, rather than on abstract philosophical rights, was highly appropriate, leaving the issue of physician-assisted suicide where it belongs-in the political process. Part III considers the nature of legal reasoning and the judicial process and finds only a limited place for philosophy. Part III also concludes that the reference to a philosopher is often a backdoor means to bring a controversial decision within the respectable mainstream-masking the contentious policy choice being made. Finally, Part IV addresses the underlying differences in method.

\section{THE EMPIRICAL DATA: A SURVEY OF PHILOSOPHERS.}

The Supreme Court rarely makes explicit reference to philosophers. A search for major Western philosophers ${ }^{5}$ in the Su-

s This study involved searching for philosophers in the Westlaw Supreme Court and Supreme Court Old databases, which together include all Supreme Court decisions. The databases were searched for references to the following philosophers: Aristotle, Thomas Aquinas, Jeremy Bentham, Edmund Burke, Jacques Derrida, René Descartes, Ronald Dworkin, Michel Foucault, Hans-Georg Gadamer, Hegel, Martin Heidegger, Thomas Hobbes, David Hume, Immanuel Kant, Gottfried Leibniz, John Locke, Niccolò Machiavelli, John Stuart Mill, Montesquieu, Thomas Nagel, Friedrich Nietzsche, Robert Nozick, Plato, 
preme Court database on Westlaw revealed that in its entire history, the Court has made reference to these major philosophers in only forty-seven cases. ${ }^{6}$ These forty-seven cases include only those

John Rawls, Jean-Jacques Rousseau, Jean-Paul Sartre, Thomas Scanlon, Arthur Schopenhauer, Adam Smith, Baruch Spinoza, Judith Jarvis Thomson, Alexis de Tocqueville, and Ludwig Wittgenstein.

This list of philosophers, although both subjective and incomplete, includes the thinkers widely regarded to be among the most influential in the Western tradition. The list also includes the six contemporary authors of the Philosophers' Brief. Of course, the study raises the larger question about "what is a philosopher?" This Comment does not undertake to answer such a question, and includes in the survey those major moral and political philosophers primarily concerned with individual rights. Further research beyond the scope of this survey might consider the role of natural law philosophers, such as Grotius and Vattel, who were cited extensively throughout the nineteenth century. As for empirical accuracy, the Court references philosophers so infrequently that the addition of a philosopher would likely not have a material effect on the survey.

The creation of this list of philosophers was based in part on A.J. Ayer and Jane O'Grady, A Dictionary of Philosophical Quotations (Blackwell 1994). While these philosophers are considered within the Western tradition, there is clearly much controversy concerning who are considered the significant thinkers. See William J. Bennett, To Reclaim a Legacy: A Report on the Humanities in Higher Education 10 (Natl Endow for the Humanities 1984) (listing important authors and recognizing that legitimate debate can exist about the most significant thinkers and the books that all students should read, but also noting that "there is more consensus on what the important books are than many people have been willing to admit").

- In chronological order, these are the forty-seven cases and the philosopher(s) that each one references: Fletcher $v$ Peck, 10 US 87, 121 (1810) (Montesquieu and Adam Smith); Green $v$ Biddle, 21 US 1, 36 (1821) (Montesquieu); Bank of Augusta $v$ Earle, 38 US 519, 538, 571 (1839) (Montesquieu and Tocqueville); United States $v$ Wood, 39 US 430, 438 (1840) (Montesquieu); Dodge v Woolsey, 59 US 331, 371 (1855) (Bentham); Christ Church Hospital v Philadelphia, 65 US 300, 302 (1860) (Bentham); Ex parte Garland, 71 US 333, 388 (1866) (Miller dissenting) (Montesquieu); Slaughter-House Cases, 83 US 36, 110 n 39 (1872) (Field dissenting) (Adam Smith); Trist $v$ Child, 88 US 441, $450 \mathrm{n} 22$ (1874) (Montesquieu); Farrington v Tennessee, 95 US 679, 682 (1877) (Montesquieu); Pollock $v$ Farmers' Loan \& Trust Co, 157 US 429, 556, 559 (1895) (Burke and Adam Smith); Beley v Naphtaly, 169 US 353, 360 (1898) (Aristotle); Kawananakoa v Polyblank, 205 US 349, 353 (1907) (Hobbes); German Alliance Insurance Co v Lewis, 233 US 389, 416 (1914) (Adam Smith); Grant Timber \& Manufacturing Co v Gray, 236 US 133, 134 (1915) (Kant); Myers $v$ United States, 272 US 52, 116, 230, 234 (1926) (majority opinion and McReynolds's dissenting opinion) (Montesquieu); United States $v$ Miller, 307 US 174, 179 (1939) (Adam Smith); Douglas v City of Jeannette, 319 US 157, 166 (1943) (Jackson concurring in part and dissenting in part) (Plato); Mercoid Corp v Mid-Continent Investment Co, 320 US 661, 673 (1944) (Black concurring) (Adam Smith); In re Oliver, 333 US 257, 271 (1948) (Bentham); Poe v Ullman, 367 US 497, 514-15 (1961) (Douglas dissenting) (Kant and Mill); Harper $v$ Virginia State Board of Elections, 383 US 663, 685 n 9 (1966) (Harlan dissenting) (Aristotle and Tocqueville); Lindsey $v$ Normet, 405 US 56, 68 n 14 (1972) (Kant); Barker $v$ Wingo, 407 US 514, 520 n 10 (1972) (Bentham); Branzburg $v$ Hayes, 408 US 665, 688 n 26 (1972) (Bentham); Roe $v$ Wade, 410 US 113, 131 (1973) (Aquinas, Aristotle, and Plato); Paris Adult Theatre $v$ Slaton, 413 US 49, 111 (1973) (Brennan dissenting) (Plato); Lakeside v Oregon, 435 US 333, 340 n 10 (1978) (Bentham); United States v Ceccolini, 435 US 268, 281 n 2, 284 (1978) (Burger concurring) (Sartre and Wittgenstein); Bell $v$ Wolfish, 441 US 520, 581 n 10 (1979) (Stevens dissenting) (Kant); Gannett Co v DePasquale, 443 US 368, 419-20, 422, 448 (1979) (Blackmun concurring in part and dissenting in part) (Bentham); Richmond Newspapers, Inc $v$ Virginia, 448 US 555, 569 n 7 (1980) (Bentham); Hewitt $v$ Helms, 459 US 460, 484-85 (1983) (Stevens dissenting) (Dworkin discussing 
in which the Court has discussed or referenced a philosopher as a philosophical thinker, and not those cases in which a "philosopher" is cited for a predominately historical, economic, or legal principle. ${ }^{7}$ While the distinction between a citation to a philosopher qua philosopher and to a philosopher qua historian, economist, or lawyer is hard to draw, most cases present fairly clear distinctions.

In these forty-seven cases, most of the references to philosophers are brief: for example, the Court will state a rather broad proposition, follow it with a simple "See Kant, Perpetual Peace," but fail to provide a quotation or explanation of why such a work might be of relevance to the case. ${ }^{8}$ The "citations" to philosophers occur in different forms. Sometimes the Court cites philosophers for substantive ideas; ${ }^{9}$ other references stand simply for a broad

Mill); Garcia v San Antonio Metropolitan Transit Authority, 469 US 528, 572, 582 (1985) (Powell dissenting; O'Connor dissenting) (Nagel); Mitsubishi Motors Corp v Soler Chrysler-Plymouth, Inc, 473 US 614, 665 n 41 (1985) (Stevens dissenting) (Kant); Delaware $v$ Van Arsdall, 475 US 673, 697 n 9 (1986) (Stevens dissenting) (Dworkin); Bowers $v$ Hardwick, 478 US 186, 211 (1986) (Blackmun dissenting) (Aquinas); Edwards v Aguillard, 482 US 578, 630 (1987) (Scalia dissenting) (Aristotle); Bowen v Gilliard, 483 US 587, 632-33 (1987) (Brennan dissenting) (Plato and Aristotle); Webster $v$ Reproductive Health Services, 492 US 490, 539 n 1 (1989) (Blackmun dissenting) (Dworkin); Barnes v Glen Theatre, Inc, 501 US 560, $587 \mathrm{n} 1$ (1991) (White dissenting) (Aristotle); Morgan $v$ Illinois, 504 US 719, 752 (1992) (Scalia dissenting) (Kant); Arave v Creech, 507 US 463, 479 n 1 (1993) (Blackmun dissenting) (Bentham); City of Ladue $v$ Gilleo, 512 US 43, 56 n 14 (1994) (Aristotle); Missouri $v$ Jenkins, 515 US 70, 133 (1995) (Thomas concurring) (Nagel); Rosenberger $v$ Rector and Visitors of the University of Virginia, 515 US 819, 836-37 (1995) (Plato, Spinoza, Descartes, and Sartre); United States $v$ Virginia, 518 US 515, 116 S Ct 2264, 2286 n 20 (1996) (Plato).

For each case that referenced a philosopher, the context in which the Court cited the philosopher was analyzed. The case was then eliminated from the survey if the philosopher was invoked by an advocate and not by the Court, or was referred to in a context involving distinctly historical, legal, or economic authority. Because this Comment seeks to examine how judicial decisions use philosophers and philosophical reasoning, references to Hume's histories or Adam Smith's distinctively economic theories were removed from the survey. For example, the following cases were excluded from the survey: Paul $v$ Virginia, 75 US 168, 171-72 (1868) (citing Adam Smith for the proposition that trading corporations and their commerce was well-known and therefore that the power "to regulate commerce" includes corporations); Keck v United States, 172 US 434, 461 (1899) (Brown dissenting) (referencing Hume in a discussion about the historical definition of smuggling); Ex parte Milligan, 71 US 2, 65 (1866) ("England owes more of her freedom, her grandeur, and her prosperity to [the jury trial], than to all other causes put together. . . . Montesquieu and De Tocqueville speak of it with an admiration as rapturous as Coke and Blackstone.") (excluded because statement of advocate, not the Court).

${ }^{8}$ See, for example, Mitsubishi Motors Corp $v$ Soler Chrysler-Plymouth, Inc, 473 US 614, 665 n 41 (1985) (Stevens dissenting), citing Kant, Perpetual Peace, A Philosophical Sketch, in Kant's Political Writings 93 (Oxford 1971) (Nisbet trans) (H. Reiss, ed), among other sources, in a footnote after the following statement: "The Courts repeated incantation of the high ideals of 'international arbitration' creates the impression that this case involves the fate of an institution designed to implement a formula for world peace."

' See, for example, Green $v$ Biddle, 21 US 1, 36 (1821) (citing Montesquieu as support 
principle; $;^{10}$ and occasionally the Court invokes philosophers only for comparison. ${ }^{11}$ The survey includes all of these various uses.

Citations to philosophers occur primarily outside of majority opinions, suggesting that the citations lack-or replace-precedential authority. The placement of these citations in concurring or dissenting opinions suggests that philosophical reasoning does not carry much weight with the Court. Of the forty-nine opinions in forty-seven cases that reference philosophers, twenty are dissents and three are concurrences-thus, almost 50 percent of opinions referencing philosophers are not majority ones. Moreover, more than half of all opinions referencing philosophers have occurred since 1950, and twenty-one of the forty-nine opinions have been in the last twenty years.

Supreme Court Opinions Citing Philosophers

\begin{tabular}{|ccccc|}
\hline Years & Total & Majority & Dissenting* & Concurring \\
$1789-1825$ & 2 & 2 & 0 & 0 \\
$1826-1850$ & 2 & 2 & 0 & 0 \\
$1851-1875$ & 5 & 3 & 2 & 0 \\
$1876-1900$ & 3 & 3 & 0 & 0 \\
$1901-1925$ & 3 & 3 & 0 & 0 \\
$1926-1950$ & 6 & 3 & 2 & 1 \\
$1951-1975$ & 7 & 4 & 3 & 0 \\
$1976-1997$ & 21 & 5 & 14 & 2 \\
\hline Total & 49 & 25 & 21 & 3 \\
\hline
\end{tabular}

* Opinions dissenting in part, and concurring in part, are counted as dissents.

An admitted problem with this empirical study is that it does not include cases in which the Court relied on or was influenced by philosophy but included no direct citation. Thus, the extent to which the Court relies on philosophers and philosophical ideas may be greater than the data suggests. Nonetheless, this Comment does not attempt to analyze philosophical influence on the Court, but rather considers how the Court uses philosophers as

for the idea that laws should encourage industry).

${ }^{10}$ See, for example, United States v Ceccolini, 435 US 268, 284 (1978) (Burger concurring) (citing Wittgenstein to describe the concept of the freedom of the will).

"See, for example, Rosenberger $v$ Rector and Visitors of University of Virginia, 515 US 819, 836-37 (1995) ("Were the prohibition applied with much vigor at all, it would bar funding of essays by hypothetical student contributors named Plato, Spinoza, and Descartes .... And if the regulation covers, as the University says it does ...., those student journalistic efforts which primarily manifest or promote a belief that there is no deity and no ultimate reality, then under-graduates named Karl Marx, Bertrand Russel, and JeanPaul Sartre would likewise have some of their major essays excluded from student publications."). 
sources to reach legal conclusions. The Court's hesitance to cite philosophers may reflect an implicit recognition that the sources of law in the Anglo-American tradition come primarily from common law customs and understandings. This survey may accurately reveal the extent to which the Court considers philosophers legitimate sources for its legal decisions. The survey raises the interesting question of why, when philosophers are used and cited extensively by legal academics, the Court rarely references these thinkers. ${ }^{12}$

\section{A. An Increased Reliance on Philosophy}

The survey demonstrates that philosophical references have become more frequent, and their context has shifted to controversial policy questions. The Court's use of philosophers has evolved over time and may correspond to increased judicial overreaching. Throughout its history the Court has at times been accused of stepping beyond its institutional limits and engaging political, rather than legal, questions. Arguably, the contemporary use of philosophers has been one means for the Court to extend its reach further.

In the nineteenth century, Supreme Court decisions quoted philosophers at greater length than more contemporary opinions, but virtually all references were to Montesquieu, whose $L^{\prime} E$ sprit des Loix was repeatedly cited for propositions of limited government, balance of powers, and the need for virtuous citizens. ${ }^{13}$ As the nineteenth century was a time when the fundamental principles of American government were still being affirmed and fully articulated, the Court's reference to such thinkers seems natural and appropriate, especially because many references were to the principles of separation of powers and the institutional limits of the Court. ${ }^{14}$

${ }^{12}$ Part of the Court's hesitance to cite philosophers might have to do with the fact that philosophers exist in the "background" of social discourse, rather than in the "foreground" of legal practice. For an excellent discussion of how background discourses can shift the law's understanding of its own sources and nature, see Lawrence Lessig, Understanding Changed Readings: Fidelity and Theory, 47 Stan L Rev 395, 411-12, 438-39 (1995).

${ }^{13}$ See, for example, Trist $v$ Child, 88 US 441,450 (1874) ("The foundation of a republic is the virtue of its citizens. They are at once sovereigns and subjects. As the foundation is undermined, the structure is weakened. When it is destroyed, the fabric must fall. Such is the voice of universal history."); Farrington v Tennessee, 95 US 679, 682 (1877) (citing Montesquieu for the idea that a republican government depends on the virtue of its citizens).

"See, for example, Myers $v$ United States, 272 US 52, 116 (1926); id at 230, 234 (McReynolds dissenting); Ex parte Garland, 71 US 333, 388 (1866) (Miller dissenting). 
In the twentieth century, and especially in the last forty years, the Court has referenced a larger variety of philosophers to support many nonlegal arguments. Recent cases go beyond political philosophers such as Montesquieu, Alexis de Tocqueville, and Adam Smith and mention theologians, existentialists, and linguists such as Thomas Aquinas, ${ }^{15}$ Jean-Paul Sartre ${ }^{16}$ and Ludwig Wittgenstein ${ }^{17}$ in discussions of reproductive rights, prohibitions against sodomy, and the suppression of evidence obtained through an illegal search. ${ }^{18}$ These references generally do not follow substantive philosophical propositions, but rather support or attack certain policy issues. As American society becomes more heterogeneous, the Court faces more controversial and political issues, such as sexual ethics, sexual equality, social class, and religion. Instead of deciding these cases in a way that would leave controversial decisions to the states and the political process, the Court has often developed fundamental rights and given an expansive reading of the Due Process Clause of the Fourteenth Amendment. To avoid criticisms of judicial activism, the Supreme Court, both in majority and dissenting opinions, may rely on philosophers.

\section{B. The Court's Use of Philosophers}

An examination of particular cases reveals how the justices have used philosophers in controversial settings to express their own policy preferences or to reach conclusions not required by more conventional legal reasoning that utilizes analogy, judicial precedent, and the text of the Constitution. By considering the cases in a roughly chronological manner, this Part shows that philosophical references appear more frequently in recent times

${ }^{15}$ See Roe $v$ Wade, 410 US 113, 134 (1973) (explaining that the common law notion of “quickening" might have its source in “Aquinas' definition of movement as one of the two first principles of life").

${ }^{16}$ See Ceccolini, 435 US at 281 (Burger concurring) (noting that the decision of the Court did not require a "judicial excursion into an area about which 'philosophers have been able to argue endlessly,' namely, the degree of 'free will' exercised by a person when engaging in an act such as speaking"), quoting Jean-Paul Sartre, Being and Nothingness 433 (Philosophical Library 1956) (Barnes trans).

${ }^{17}$ Ceccolini, 435 US at 284 (Burger concurring) ("As one philosopher has aptly stated the matter, " $[t]$ he freedom of the will consists in the impossibility of knowing actions that still lie in the future."), quoting L. Wittgenstein, Tractatus Logico-Philosophicus II 5.1362 (Cornell 1971) (Pears \& McGuinness trans).

${ }^{18}$ This increased and diverse use of philosophers may correspond to the decline in the autonomy of law. Judge Richard Posner attributes the decline in the autonomy of law to, among other things, the shattering of political consensus in American society. Richard A. Posner, The Decline of Law as an Autonomous Discipline: 1962-1987, 100 Harv L Rev 761, 766-67 (1987). On the autonomy of the law, see also Section III.A. 
to support policy decisions. In order to cover a narrow legal point, however, these philosophical references often occur out of context and distort the larger arguments made by the philosopher.

\section{Philosophy as a source for prejudice.}

In early nineteenth century cases, the Court referenced philosophers to give foundational support for historical prejudices. For example, in cases concerning the property rights of Native Americans, the Court invoked political and moral philosophers to deny this minority group their right to traditional lands. In Fletcher $v$ Peck, ${ }^{19}$ the Court briefly cited Montesquieu and Adam Smith to justify its distinction between the Anglo-American conception of land and that of the Native Americans: "What is the Indian title? It is a mere occupancy for the purpose of hunting. It is not like our tenures; they have no idea of a title to the soil itself. It is overrun by them, rather than inhabited. It is not a true and legal possession."20

In more modern cases, the Court has turned to philosophers when considering controversial issues of social class and race. As white male dominance over the political process has become less accepted, defenders of the status quo have had to reach deeper into the philosophical tradition to justify their views. For example, in Harper $v$ Virginia State Board of Elections, ${ }^{21}$ the Court held that Virginia's poll tax violated the Equal Protection Clause of the Fourteenth Amendment because wealth "is not germane to one's ability to participate intelligently in the electoral process."22 In a dissenting opinion, Justice Harlan defended the historical support for property qualifications for the franchise and cited Aristotle and Tocqueville for support. ${ }^{23}$

10 US 87 (1810).

${ }^{20}$ Id at 121, citing Montesquieu, The Spirit of the Laws Book 18, ch 12 (describing the frequent strife that arises between peoples who have no "landed property"); Adam Smith, An Inquiry into the Nature and Causes of the Wealth of Nations Book 5, ch 1 (referring to nations of hunters as "the lowest and rudest state of society" in which "there is properly neither sovereign nor commonwealth").

${ }^{21} 383$ US 663 (1966).

2 Id at 668 .

${ }^{23}$ Id at 685 (Harlan dissenting) (discussing the long-held view that people who own property "have a deeper stake in community affairs, and are consequently more responsible, more educated, more knowledgeable, more worthy of confidence, than those without means, and that the community and Nation would be better managed if the franchise were restricted to such citizens"), citing Aristotle, Politics Books 3, 4 (Oxford 1885) (Jowett trans) (defining the concept of a "state" and discussing the best forms of government); Alexis de Tocqueville, Democracy in America ch 13 at 199-202 (Knopf 1948). Here, Justice Harlan uses political theory to characterize the significance of property ownership. 
2. Sexual reproduction and ethics: Plato supports abortion?

In recent cases involving changing sexual ethics, the Court has invoked traditional and easily recognized philosophical figures to support contested political positions. In Poe $v$ Ullman, ${ }^{24}$ the Court dismissed a challenge to Connecticut's contraception statute because it did not involve a constitutional question. ${ }^{25}$ In his dissenting opinion, Justice Douglas made extensive use of philosophers, invoking both Kant and Mill, to defend the right of a doctor to discuss birth control options with a married couple:

These are [the doctor's] professional domains into which the State may not intrude. The chronicles are filled with sad attempts of government to stomp out ideas, to ban thoughts because they are heretical or obnoxious. As Mill stated, "Our merely social intolerance kills no one, roots out no opinions, but induces men to disguise them, or to abstain from any active effort for their diffusion. ${ }^{326}$

In perhaps the most disputed decision in recent history, the Court in its majority opinion in Roe $v$ Wade ${ }^{27}$ discussed the approval of abortion by some ancient Greeks. Although the Hippocratic Oath, still sworn by doctors today, provides that a doctor "will not give to a woman an abortive remedy," the Court argued that the Oath was not widely accepted in Greek society and that both Plato and Aristotle supported abortion, at least prior to viability. ${ }^{29}$ The Court never explains why Plato and Aristotle should be considered authority for such a controversial moral and political issue, or how the support of philosophers provides a persua-

24 367 US 497 (1961).

${ }^{25}$ Id at 508-09.

Id at 514-15 (Douglas dissenting), citing John Stuart Mill, On Liberty of Thought and Discussion, 43 Great Books 282. Justice Douglas also wrote, "We should say with Kant that 'It is absurd to expect to be enlightened by Reason, and at the same time to prescribe to her what side of the question she must adopt.' Leveling the discourse of medical men to the morality of a particular community is a deadening influence." 367 US at 514, citing Immanuel Kant, Critique of Pure Reason, 42 Great Books 221.

${ }^{27} 410$ US 113 (1973).

L. Edelstein, The Hippocratic Oath 6 (Ares 1979).

2 Roe, 410 US at 131 (arguing that only the Pythagorean school of thought opposed abortion, while "[m]ost Greek thinkers, on the other hand, commended abortion, at least prior to viability"). The Court cites to Plato's Republic, Book V, 461; however, in this portion of the dialogue, Plato does not commend abortion prior to viability. Rather he discusses the importance of not having children beyond one's prime in life, explaining to Glaucon that those beyond their prime may have intercourse "only after they have been told to be especially careful never to let even a single foetus see the light of day, if one should be conceived." The Republic of Plato, Book V, 461c (BasicBooks 1968) (Bloom trans). While this acknowledges the occasional need for abortion, it is hardly a commendation of it. The Court also cites Aristotle, The Politics, VII, 1335b 25. 
sive legal or institutional argument for the Court's expansion of privacy rights. ${ }^{30}$ Rather, the Court uses esteemed philosophers to legitimize a controversial perspective. By contrast, there were many persuasive legal arguments against recognizing a constitutional right to abortion. For instance, substantive due process arguably has no textual support in the Fourteenth Amendment Due Process Clause, and was at any rate severely discredited after the Lochner era. ${ }^{31}$ Furthermore, most states have historically prohibited abortion. The Texas statute struck down in Roe was enacted in 1857, and had remained virtually unchanged until the Court's decision in Roe. ${ }^{32}$

This trend of referring to philosophers for support in controversial cases has continued in recent cases on sensitive gender issues. In Barnes $v$ Glen Theatre, Inc, ${ }^{33}$ the Court upheld the constitutionality of a public indecency statute requiring exotic dancers to wear pasties and g-strings. ${ }^{34}$ Justice White's vociferous dissent argued that such a statute violated the First Amendment, and indeed that "Aristotle recognized in Poetics that the purpose of dance is 'to represent men's character as well as what they do and suffer." 35 While Aristotle's views on the human qualities of dance might be relevant to public discourse on the subject of indecency statutes, Justice White failed to explain how wearing a gstring detracted from the expressive suffering of exotic dancers, or how his views were relevant to whether the indecency statute violated the First Amendment.

In a challenge to the Virginia Military Institute's ("VMI") single-sex model of education, Justice Ginsburg, writing for the Court, defended the right of women to be admitted to that prestigious institution. ${ }^{36}$ Justice Ginsburg cited a contemporary scholar for the proposition that even in Plato's society, "women's native ability to serve as guardians was not seriously ques-

${ }^{30}$ This kind of superficial use of philosophers may have an unanticipated twist: the average citizen may recognize Plato and Aristotle as respected philosophers, but may not be aware of the reigning sexual ethics of ancient Greece that included the almost complete subjugation of women and widespread homosexuality, two ideas out of step with mainstream American culture. When the Court refers to philosophers' moral views out of the context of their culture and philosophical works, it might be guilty of rhetorical dishonesty.

${ }^{31}$ See, for example, Cass R. Sunstein, Lochner's Legacy, 87 Colum L Rev 873, 874 \& nn 6-8 (1987) (discussing "received wisdom" that Lochner was "wrong because it involved judicial activism").

${ }^{32}$ Roe, 410 US at 175-77 (Rehnquist dissenting).

${ }^{33} 501$ US 560 (1991).

${ }^{34}$ Id at 565 .

${ }^{35}$ Id at $587 \mathrm{n} 1$ (White dissenting).

${ }^{35}$ United States v Virginia, 518 US 515, 116 S Ct 2264, 2276 (1996). 
tioned. ${ }^{37}$ Justice Ginsburg further elaborated that the only real question about women serving as military defenders in the Greek army concerned physical training, which customarily occurred in the nude. ${ }^{38}$

There are a number of aspects in which the Courts reliance on Plato is suspect. First, one could challenge the historical accuracy of Justice Ginsburg's claims. Perhaps Plato never questioned a woman's ability to serve as a guardian because in the maledominated Greek society, in which women played no political or social role outside of the home, the idea of a woman serving in such a highly visible and prestigious position was unimaginable. Second, the Court does not use Plato's philosophical ideas, but only his views of gender relations as interpreted by a modern scholar. This once-removed interpretation is less persuasive than a direct reading of Plato, because the scholar lacks the intellectual authority possessed by a philosopher of Plato's stature. Even if the historical characterization is accurate, Plato's ideas have more relevance to the social and political climate of ancient Athens than to modern American judicial decision making. Finally, the Court does not explain how Plato's views on single-sex military education are germane to the integration of VMI, nor how the guardians of Athens are analagous to the officers being trained at VMI. These examples illustrate the increasing tendency of the Court to use philosophers to support contested political positions. In contrast, the next Part considers in detail one of the most high profile failures of philosophy to serve as a source for the law.

\section{The JUdiciall AND PhIlosophical Right to DiE}

A comparison of Chief Justice Rehnquist's opinion in Glucksberg and the Philosophers' Brief serves as a good case study in the marked differences between philosophers and judges in both their goals and their methods of reasoning. After outlining the procedural history in Glucksberg, Chief Justice Rehnquist writes:

We begin, as we do in all due-process cases, by examining our Nation's history, legal traditions, and practices. . . . In almost every State-indeed, in almost every western democracy-it is a crime to assist a suicide. The States' assisted-

${ }^{37}$ Id at 2287 n 20, citing Beryl J. Levine, Closing Comments, 6 L \& Inequality 41, 41 (1988). Note that for this point Justice Ginsburg did not draw upon the original Platonic text, but rather referenced the interpretive comments of a modern philosopher.

${ }^{3}$ Virginia, $116 \mathrm{~S}$ Ct at $2287 \mathrm{n} 20$. For Plato's full text on the equality of women, see 2 The Dialogues of Plato Book V (Oxford 4th ed 1953) (Jowett trans). 
suicide bans are not innovations. Rather, they are longstanding expressions of the States' commitment to the protection and preservation of all human life. ${ }^{39}$

Chief Justice Rehnquist cites numerous cases on suicide in which the Court has relieu" on historical practice. ${ }^{40} \mathrm{He}$ proceeds, "More specifically, for over 700 years, the Anglo-American common-law tradition has punished or otherwise disapproved of both suicide and assisting suicide. ${ }^{\$ 41}$ Basing his arguments on historical understandings and precedent, Chief Justice Rehnquist elaborates on the significant religious, social, and political traditions against the taking of one's own life. Although the Court appropriately considers the changing conditions of modern society, it does not retreat from the historical prohibition against suicide. ${ }^{42}$ Chief Justice Rehnquist concludes that the Constitution did not contemplate the protection of a right to physician-assisted suicide. ${ }^{43}$

Further, Chief Justice Rehnquist's historical arguments advocate judicial restraint based on institutional limitations. The Court will uphold "substantive" due process rights only when required by history and tradition. Limited institutional authority should constrain the Court from deciding a moral and political question such as physician-assisted suicide. ${ }^{44}$ Chief Justice Rehnquist did not approve of the State's ban on assisted suicide per se, but rather used history and tradition to show that assisted suicide was not a protected right under the Fourteenth Amendment. ${ }^{45} \mathrm{He}$ argued that the debate over assisted suicide-one with

$39117 \mathrm{~S} \mathrm{Ct}$ at 2262-63 (citations omitted) (emphasis added).

to Id ("[O]pposition to and condemnation of suicide-and therefore, of assisting suicide-are consistent and enduring themes of our philosophical, legal, and cultural heritages.").

4 Id at 2263 (referring to Henry de Bracton and William Blackstone, who wrote in the thirteenth and early nineteenth centuries, respectively).

${ }^{12}$ Id at 2267-68.

${ }^{43}$ Id at 2271.

4 For a good discussion of the institutional limitations of courts, see Cass R. Sunstein, From Theory to Practice, 29 Ariz St L J 389, 400-04 (1997). Sunstein notes that:

[C]ourts generally seek, because of their own understanding of their limited capacities, to offer low-level rationales on which diverse people may converge. This is so especially when the consequence of theoretical ambition would be to invalidate the outcomes of democratic processes; it is here that the Court properly proceeds cautiously, again because of its understanding of its limited capacities in thinking about philosophical abstractions.

Id at 401.

${ }^{45} 117 \mathrm{~S} \mathrm{Ct}$ at 2271 ("The history of the law's treatment of assisted suicide in this country has been and continues to be one of the rejection of nearly all efforts to permit it. That being the case, our decisions lead us to conclude that the asserted 'right' to assistance in committing suicide is not a fundamental liberty interest protected by the Due Process Clause."). 
deep moral and political implications-should continue and be resolved through democratic deliberation: "Throughout the Nation, Americans are engaged in an earnest and profound debate about the morality, legality, and practicality of physician-assisted suicide. Our holding permits this debate to continue, as it should in a democratic society. ${ }^{346}$

In contrast to the Court in Glucksberg, the Philosophers' Brief asserts that individuals have a protected liberty interest to make certain decisions for themselves ${ }^{47}$ For this weighty proposition the philosophers begin with dicta from the highly controversial decision in Planned Parenthood $v$ Casey: "At the heart of liberty is the right to define one's own concept of existence, of meaning, of the universe, and of the mystery of human life. ${ }^{488}$ The philosophers strive to view the problem of assisted suicide from its rational foundations, as an individual question of conscience. Seen in this light, the Due Process Clause of the Fourteenth Amendment protects the liberty interest of certain life decisions. The philosophers argue, "Such deeply personal decisions pose controversial questions about how and why human life has value. In a free society, individuals must be allowed to make those decisions for themselves, out of their own faith, conscience and convictions. $\$$

Concededly, the philosophers do attempt more conventional legal arguments. For example, they discuss the Court's expansion of privacy rights in Casey ${ }^{50}$ and Cruzan v Missouri Department of Health ${ }^{51}$ and also the states' interests in regulating suicide. ${ }^{52} \mathrm{De}-$ spite these arguments, the underlying focus of the brief is moral, not legal. The interest of the philosophers is stated as their "respect for fundamental principles of liberty and justice, as well as for the American constitutional tradition. ${ }^{.53}$ It is significant that the fundamental principles precede the philosophers' regard for the American tradition.

The approaches taken by the Supreme Court and the philosophers to assisted suicide could not be more different. Chief

${ }^{48}$ Id at 2275.

171996 WL 708956 at $* 5$.

*3 Id, discussing Casey, 505 US 833, 851-52 (1992) (holding that a woman has a right to have an abortion, and that right cannot be unduly burdened).

1996 WL 708956 at *5.

${ }^{30}$ Id at *8-9, citing Casey, 505 US at 851-52.

31 1996 WL 708956 at *9-12, citing Cruzan, 497 US 261, 287-89 (1990) (holding that a competent person has a constitutionally protected liberty interest in refusing unwanted treatment).

${ }^{52} 1996$ WL 708956 at $* 12-20$.

${ }^{53}$ Id at *2 (emphasis added). 
Justice Rehnquist relies on history and a long social and legal tradition forbidding suicide, arguing that the Due Process Clause protects those fundamental rights and liberties that are "objectively, 'deeply rooted in this Nation's history and tradition." philosophers advance only an abstract notion of liberty and do not offer a contrary historical narrative. Instead they put forward their own moral and political ideas, derived from a rational inquiry into the nature of an individual's liberty interest, and supported by only the weakest judicial authority. Perhaps the philosophers avoid history because another historical narrative does not exist; it seems clear that the Anglo-American tradition, and indeed, most of Western tradition, remains solidly against suicide. Given the importance of history and tradition in defining what constitutes a "fundamental right" under the Due Process Clause of the Fourteenth Amendment, ${ }^{55}$ it seems remarkable that the philosophers made no argument for their position from history and tradition. These salient differences in tone and focus exemplify the divergence between philosophers and judges and are further explored in the next Part.

\section{AN INQUIRY INTO THE JUDICIAL PROCESS}

The relationship between philosophy and judicial decision making raises an important question about the nature of judicial activity. What is it that judges do when they decide cases? How do they reach their conclusions? Perhaps most importantly, what sources of authority should and do provide support for judicial opinions? ${ }^{56}$ The use of philosophy by the Court relates to pressing concerns among legal scholars about the nature of legal study and legal reasoning. This Part first shows that law is not completely autonomous and so philosophy might have a role to play in the law. Next, it argues that the use of philosophy by courts should be limited, because such use tends to correspond with po-

${ }^{54}$ Glucksberg, $117 \mathrm{~S}$ Ct at 2268, citing Moore $v$ East Cleveland, 431 US 494, 503 (1977) (plurality opinion).

${ }^{\text {ss }}$ Glucksberg, $117 \mathrm{~S} \mathrm{Ct}$ at 2268.

${ }^{6}$ In response to some of these elusive questions, Justice Benjamin Cardozo tried to articulate what judges do when they decide cases but recognized that there was little hope of stating a persuasive formula. He wrote:

What is it that I do when I decide a case? To what sources of information do I appeal for guidance? ... If a precedent is applicable, when do I refuse to follow it? If no precedent is applicable, how do I reach the rule that will make a precedent for the future? ... At what point shall the quest be halted by some discrepant custom, by some consideration of the social welfare, by my own or the common standards of justice and morals?

Benjamin N. Cardozo, The Nature of the Judicial Process 10 (Yale 1964). 
litical judgments of the kind best left to the democratically accountable legislatures.

\section{A. Philosophy as a Legal Source}

In order to find a place for philosophy in the law, it is important to determine which sources best support judicial decision making. Christopher Langdell, one of the great avatars of formal legal education, believed that knowledge and understanding of the law could be derived scientifically from legal sources such as cases and statutes. ${ }^{57}$ This kind of legal positivism left little room for other disciplines in legal education and emphasized the autonomy of the law. Langdell's perspective has suffered greatly in the past thirty years, as disciplines such as economics, history, and philosophy have come to play a larger role in legal scholarship. Law and economics scholars such as Judge Richard Posner argue that there has been a decline in the autonomy of the law. ${ }^{58}$ The critical legal studies movement similarly emphasizes the lack of independence in the law and the law's subordination to politics. $^{59}$

Langdell's vision, however, is not dead yet. In the wake of new legal movements like law and economics and critical legal studies, scholars such as Owen Fiss lament the "death of the law. ${ }^{.560}$ Fiss has argued that the law, through its particular mode of reaching decisions, has a unique role in ascertaining and promoting public values. ${ }^{61}$ Other so-called neotraditionalists also maintain law's autonomy from other disciplines and argue for the unique and special nature of legal reasoning. ${ }^{62}$

This Comment supports a softened version of the neotraditionalist view, namely that law is semi-autonomous. The law might reference other disciplines, but primarily it should retain its distinct methods and forms of reasoning. Richard Fallon re-

${ }^{37}$ Although Langdell's views on legal education have been widely influential, and although he is credited with beginning the case law method of legal teaching, Langdell never formally presented his views. Other scholars, however, have discussed them. See, for example, Anthony T. Kronman, The Lost Lawyer: Failing Ideals of the Legal Profession 170-74 (Belknap 1993).

${ }^{58}$ See Posner, 100 Harv L Rev at 761 (cited in note 18).

See, for example, Roberto Mangabeira Unger, The Critical Legal Studies Movement, 96 Harv L Rev 561, 563-66 (1983) (emphasizing the political nature of the law).

${ }^{\infty}$ Owen M. Fiss, The Death of the Law?, 72 Cornell L Rev 1, 16 (1986).

${ }^{61}$ Id at 15-16 ("We need public morality to have law, true, but even more, we need law to have a public morality.").

"See, for example, Charles Fried, The Artificial Reason of the Law or: What Lawyers Know, 60 Tex L Rev 35, 38 (1981) (arguing that "law is a distinct subject, a branch neither of economics nor of moral philosophy, and that it is in that subject that judges and lawyers are expert"); Fiss, 72 Cornell L Rev at 18 (cited in note 60). 
flects a similar view when he describes how courts really operate: "Legal reasoning is distinctively reasoning about past political decisions and their current implications within a set of interpretive conventions that is in some ways peculiar to the law. Even when it borrows from other disciplines, law is a distinctive practice, with its own reality-making set of concepts, conventions and expectations. ${ }^{363}$ Thus, under this approach, nonlegal theory can supplement the law, but it does not supplant its particular form of reasoning.

Fallon argues that judges "commonly employ non-legal theories in their opinions to justify or legitimate their decisions. ${ }^{.64}$ The empirical evidence presented in Part I supports this point: the Court uses philosophers to legitimize or justify its decisions, and dissenting justices reference philosophers to lend intellectual, and often moral, support for their minority positions. ${ }^{65}$ This use of philosophers is often shallow and incomplete, because the Court does not engage substantive arguments. Rather, the Court references philosophers to generate political approval. ${ }^{66}$ Fallon argues that such "shallow" philosophical arguments might not offend the standards of acceptability in judicial decision making for two reasons. ${ }^{67}$ First, the law is a practical discipline and cases must be resolved relatively quickly, without the exacting attention to detail demanded by a philosopher. ${ }^{68}$ More importantly, legal authority often tries to mask tensions in the underlying law. Judicial opinions selectively structure precedent, statutory language, and historical understanding to suggest a single necessary outcome. Judicial decisions ought to be reassuring, and so it is tolerable that "[s]ometimes a shallow economic or philosophical analysis helps to buttress imposition of a rule dictated by precedent, when a deeper analysis would sow doubts. ${ }^{.69}$ The empirical evidence suggests that the Supreme Court implicitly adopts this view of using philosophy in its opinions. That is, the Court will sacrifice philosophical rigor to promote rule of law values such as clarity, consistency, and consensus. This superficial use lends

${ }^{6}$ Richard H. Fallon, Jr, Non-Legal Theory in Judicial Decisionmaking, 17 Harv J L \& Pub Pol 87, 88-89 (1994) (emphasis in original). Fried also argues that law is only a "relatively autonomous subject," but his view of the use of nonlegal theory is more skeptical than Fallon's. See Fried, 60 Tex L Rev at 38-39 (cited in note 62).

6 Fallon, 17 Harv J L \& Pub Pol at 89-90 (cited in note 63).

${ }^{\omega}$ See Part I.A.

${ }^{68}$ See Part I.B.

${ }^{67}$ Fallon, 17 Harv $J \mathrm{~L} \&$ Pub Pol at 93-96 (cited in note 63).

${ }^{6 s}$ Id.

Id at 94. 
support for the idea, further discussed in the next Part, that the Court uses philosophers as a surrogate for policy making.

\section{B. Congressional References to Philosophers}

The Court's increasing use of philosophers as a source may reflect a shift towards tackling more political issues. Contentious moral and political questions should be resolved primarily by Congress because of its constitutionally granted legislative powers, ${ }^{70}$ its democratic pedigree, and its deliberative safeguards. ${ }^{71}$ One thus might expect Congress to make reference to philosophers with greater frequency than the Court simply because of the political and rhetorical nature of legislative activity. Empirical evidence supports this intuition: a search of the Congressional Record database in Westlaw, which starts in 1985, found 7574 references to the earlier list of philosophers. ${ }^{72}$ Removing the names Mill and Adam Smith, which often recur in forms irrelevant to this inquiry, still results in 2981 references over a span of only thirteen years. ${ }^{73}$ By contrast, the Court has made only fortyseven such references in its entire history. ${ }^{74}$

Of course, the Congressional Record and Supreme Court opinions differ in both their methods and purposes. The Congressional Record reflects the self-conscious deliberative process of politicians, who may only be grandstanding for C-SPAN, or might have edited their speeches before inserting them into the Record. On the other hand, Supreme Court opinions are binding decisions of law, carefully drafted within certain boundaries and with reference to other cases. They are legal authority, not just debates and deliberations. Furthermore, the Congressional Record takes up thousands of pages each year, compared to the few volumes of the Supreme Court Reporter. The differences between the two sources make difficult any serious statistical comparison. Never-

${ }^{70}$ US Const, Art I, $\$ 1$ ("All legislative Powers herein granted shall be vested in a Congress of the United States.").

"The Framers were very concerned about ensuring a certain deliberative process; hence, they established structures such as a bicameral legislature and presentment. See, for example, Federalist 62, 80 (Madison), in Isaac Kramnick, ed, The Federalist Papers 364-69, 445-50 (Penguin 1987).

72 See note 5.

${ }^{73}$ Congress's use of philosophers appears, at least on a brief survey, to be just as superficial as the Court's. For instance, in a discussion of the Political Freedom in China Act of 1997, Congressman Hunter profoundly states, "I thank . . . all my colleagues who have worked so hard to see that we not only export goods from this country, but that we export goodness and morality. De Tocqueville said America is great because America is good." Proceedings on the Political Freedom in China Act, HR 2358, 105th Cong, 1st Sess, in 143 Cong Rec H 10071 (Nov 5, 1997).

${ }^{24}$ See note 6 and accompanying text. 
theless, the thousands of citations in the Congressional Record dwarf the few dozen citations by the Supreme Court. This difference may reveal that philosophers frequently serve as a legitimate source for legislative deliberation, but rarely serve the same function in judicial opinions.

\section{Policy Making in the Court}

The Court's more frequent use of philosophers as a "source" in recent opinions may indicate an increasing willingness to address policy issues, ${ }^{75}$ for which traditional legal arguments are not always sufficient. In their work on legal positivism, Frederick Schauer and Virginia Wise discuss the increasing use of nonlegal sources by the Court. ${ }^{76}$ An initial count of citations to nonlegal sources revealed that "there was no significant increase in the Court's citation of nonlegal sources from 1950 through 1990, but that starting in 1991, there has been a substantial and continuing increase in the Court's citation of nonlegal sources. ${ }^{\text {m7 }}$

Schauer and Wise note that a legal source can be viewed as a social construct-a choice of how we define the law. ${ }^{78}$ Changes in the information sources used by courts will likely have important consequences for the nature of law and how society views it. ${ }^{79}$ What counts as law depends partially on what the Court determines to be appropriate sources for the law. Broad social and political decisions often require courts to use nonlegal sources like philosophy; thus, the increasing use of nonlegal sources may indicate that courts are adjudicating more social and policy issues. Significant overlap between the sources of authority and the issues addressed by the judiciary and the legislature diminishes the distinctions between them, and makes the social function of the law less distinct. If philosophy traditionally serves as an

${ }^{75}$ See Part I.B.

${ }^{76}$ Frederick Schauer and Virginia J. Wise, Legal Positivism as Legal Information, 82 Cornell L Rev 1080, 1105-08 (1997).

7 Id at 1108. Schauer and Wise counted (rather than sampled) citations to nonlegal materials by the Supreme Court for certain select years for their study.

${ }^{73}$ Id at 1093-94. They explain:

[T] ]he idea of a legal source is more figurative than literal, and largely a construct designed to capture the idea of contingent human and social choice as the essential feature of lawness. If, for example, a society were to empower its legal decisionmakers to make decisions on the basis of their best all-things-considered moral or policy judgments, then the social decision to so empower its decisions would be the relevant social source, even though what emerged from that source was a domain of the legal that was indistinguishable from a larger moral or policy domain.

Id.

${ }^{79}$ Id at $1081-83$ 
authoritative source for legislators, but not for courts, the increasing use of philosophy by courts will have consequences for the nature of the law. ${ }^{80}$ Thus, the next Part considers why courts should hesitate to use philosophers in their opinions.

\section{THE JUDGE: NEITHER PHILOSOPHER NOR KING}

Although law has traditionally been autonomous from other disciplines, nonlegal sources and methods, including philosophy, have begun to influence scholars, lawyers, and even judges. As discussed earlier, Supreme Court justices have been referencing philosophers more frequently, especially when dealing with controversial political issues. In response to these changes in the legal Zeitgeist, this Part shows how philosophy and judicial decision making are different enterprises, and argues that judges should be wary of philosophizing in their opinions.

The fundamental differences between judges and philosophers revolve around three characteristics of judicial decision making. First, judicial decision making is a practical activity in which the judge must resolve a private or public dispute and reach a definite conclusion. A court's decision has real-world consequences that academic or philosophical arguments do not have. Second, courts face institutional constraints; they operate within a constitutional system of checks and balances and against a traditional background understanding of courts as institutions empowered only to decide a certain class of cases and controversies. Finally, courts in the Anglo-American common law system are bound by precedent and make their decisions under a strong presumption of stare decisis. The very nature of judicial decision making involves a nuanced understanding of social and political traditions, because the law operates only within this complex historical framework. This Part demonstrates how these three characteristics of judicial decision making distinguish it starkly from philosophy and allow philosophy only a limited role in the legal process.

\section{A. Practical Choices and Legal Consequences}

The differences between the philosopher and the judge are rooted in Aristotle's distinction between philosophical and practical wisdom. The philosopher aims to understand those truths

so See id at 1095 (noting that if lawyers use the same information set as others, their use would indicate substantial overlap between the legal and nonlegal). The overlap in sources between the Court and the legislature might indicate a separation-of-powers problem because constitutionally, judges should not be policy makers. 
that are universal and often abstracted from the particulars of human experience. On the other hand, the man of practical wisdom, like the judge, aims to understand political truths that involve deliberation about man. ${ }^{81}$ Aristotle believed that practical wisdom had to be concerned with more than universals because "it must also recognize the particulars; for it is practical, and practice is concerned with particulars. ${ }^{282}$ This Part will consider the works of three philosophers concerned with legal issues and will show how their approaches to the law reflect inherent tensions between legal and philosophical purposes and concerns.

Even though the life of the law might be experience and not logic, ${ }^{83}$ philosophers seeking to influence the law often do so from a theory-oriented, foundational perspective. Law lacks, according to some scholars, a serious way of explaining its judgments on moral and political issues. Ronald Dworkin, John Rawls, and Martha Nussbaum all share some version of this view. Dworkin wants judges to interpret the law to make it the best that it can be, ${ }^{84}$ which means appealing to broad notions of the just and the right. In a recent article, Dworkin praises theory and argues for its essential role in legal decision making. ${ }^{85}$ Dworkin delights in being a theorist in order to distinguish himself from what he calls the "Chicago School" - a category plastic enough to include both Richard Posner and Cass Sunstein, despite their many differences.

As a philosopher, Dworkin wants to defend the "metaphysical" view from the onslaught of "antitheorists. ${ }^{\text {" }}{ }^{\text {" Do }}$ Dorkin admits that Judge Posner gives valuable advice-_"not to lock out strange ideas, to attend to the consequences of decisions, and otherwise to conduct our intellectual and legal activities in a sage way. ${ }^{\text {"87 }}$ But as a philosopher, Dworkin is careful to point out that "this is not the stuff on which a jurisprudence is built. ${ }^{988}$ Although he recognizes the value of practice, for Dworkin, "jurisprudence" must be

${ }^{81}$ See Aristotle, The Nichomachean Ethics, Book VI, ch 7, 1141b 15-20 (Oxford 1925) (Ross trans).

\& Id at Book VI, 7.

See Oliver Wendell Holmes, The Common Law 1 (Little, Brown 1951).

8t Ronald Dworkin, Law's Empire 1-11 (Belknap 1986).

${ }^{\text {Bs }}$ Ronald Dworkin, In Praise of Theory, 29 Ariz St L J 353, 355 (1997). In response, Judge Posner argues that Dworkin establishes only one view of theory and Posner's pragmatic view can be "theorized," just not universalized into an abstract system. See Richard Posner, Conceptions of Legal "Theory": A Response to Ronald Dworkin, 29 Ariz St L J 377, 378-79 (1997). The correct distinction might not be between theory and practice, but rather between abstract and pragmatic reasoning.

${ }^{86}$ Dworkin, 29 Ariz St L J at 355 (cited in note 85).

${ }^{87}$ Id at 364.

${ }^{83}$ Id. 
based on more broad ranging metaphysical ideas. His view of theory may not be the exclusive or correct one, but it exemplifies a real distinction between prevalent theoretical, philosophical methods and more practical legal reasoning.

John Rawls implicitly shares Dworkin's perspective on the theory/practice divide. In his new work Political Liberalism, Rawls redefines his "justice as fairness" theory to account for the more practical concerns of pluralism in a deliberative democracy. ${ }^{89}$ His work is now "political, not metaphysical" and in being so, he says it "stays on the surface, philosophically speaking." Rawls considers his interest in the political and practical to be important, but philosophically shallow.

In line with other philosophers seeking to influence the law, Martha Nussbaum strongly advocates the use of philosophy in legal education. ${ }^{91}$ She argues that lawyers and judges could usefully apply more theoretical rigor to their considerations of moral issues such as justice, equality, liberty, and sexuality. ${ }^{92}$ Nussbaum's understanding of philosophy's utility comes from an attention to the concepts of justice and equality. She argues that the specifically conceptual nature of philosophical thinking can bring a fresh and deep perspective to legal training. Nussbaum's perspective may be the most constructive, not only because it explains the differences between philosophy and law, but also because it shows how philosophy can inform legal thinking. The institutional limits in the law point out the differences between the two enterprises, but do not wholly separate them. She writes:

Judges are never free to go for the best. They are constrained by history, by precedent, by the nature of legal and political institutions. This means that any philosophy that is going to be of help to the law must be flexible and empirically attentive, rather than prissy and remote. ${ }^{93}$

* John Rawls, Political Liberalism xvi-xx (Columbia 1996).

0 John Rawls, Justice as Fairness: Political Not Metaphysical, 14 Phil \& Pub Affairs 223, 230 (1985). See also Michael Sandel, Democracy's Discontent: America in Search of a Public Philosophy 17-19 (Belknap 1996) (discussing minimalist liberalism that requires bracketing moral and religious views in order to have better democratic deliberation about justice and rights).

"See, for example, Martha C. Nussbaum, The Use and Abuse of Philosophy in Legal Education, 45 Stan L Rev 1627, 1630 (1993) (arguing that several areas of legal education could benefit from the introduction of philosophy).

n Id ("Judicial opinions are full of such [theoretical] claims. Yet the discussions rarely show even the most elementary awareness of the rigorous work that philosophers have been doing, work that would very likely contribute to the clarification of the judge's or lawyer's own process of reasoning about these matters.").

${ }^{\infty}$ Id at 1643. 
Perhaps most professional philosophy is prissy and remote, but down-to-earth philosophical insights ${ }^{94}$ can undoubtedly benefit legal understanding.

Dworkin, Rawls, and Nussbaum all argue that philosophy's contribution to the law comes from its theoretical rigor and conceptual ambitiousness. But practical wisdom and deliberation form the main activities of a judge, who must focus on the particular facts and circumstances of a given situation in order to reach a conclusion in accordance with the law. ${ }^{95}$ Judicial decision making does not search for universal answers. Charles Fried argues that analogy and precedent come to the service of the law at the point where philosophy cannot provide answers to particular questions: "Analogy and precedent are the stuff of the law because they are the only form of reasoning left to the law when general philosophical structures and deductive reasoning give out, overwhelmed by the mass of particular details. ${ }^{196}$ Philosophy can help lawyers and judges understand concepts such as causation, free will, and intention; however, abstract theory can only go so far in answering highly particular claims. ${ }^{97}$

Furthermore, while human experience may be relevant to philosophical inquiry, some philosophers, like Dworkin, will remain unmoved in their opinions and theories by the ordinary world of politics and practical matters. Judge Posner criticizes this insensitivity to particulars: "As illustrated by the Philosophers' Brief that so strikingly fails to engage the many difficult institutional issues raised by its proposal of a constitutional right to physician-assisted suicide, there is little texture to Dworkin's

*t "Down-to-earth" philosophical insights might include more political philosophy, or perhaps even some economic theory. These ideas, often invoked by the Court in the nineteenth century, articulated principles for republic government and contained insights relevant to legal problems. See notes 13-14 and accompanying text.

${ }^{6}$ This nuanced and subtle approach is not necessarily unique to judicial decision making. Edmund Burke argued that the science of government was practical and therefore required both experience and caution. Edmund Burke, Reflections on the Revolution in France 53-54 (Hackett 1987) (Pocock, ed) ("The science of government being therefore so practical in itself and intended for such practical purposes-a matter which requires experience, and even more experience than any person can gain in his whole life ...-it is with infinite caution that any man ought to venture upon pulling down an edifice ... or on building it up again without having models and patterns of approved utility before his eyes.").

${ }^{\circ}$ Fried, 60 Tex L Rev at 57 (cited in note 62). See also Edward H. Levi, An Introduction to Legal Reasoning 1-6 (Chicago 1949) (explaining that legal reasoning occurs primarily by example, and this is how new social ideas enter the law).

${ }^{27}$ Fried proposes a metaphor that philosophy descends from on high but stops short of reaching the ground. The "task of the law [is] to complete this structure of ideals and values, to bring it down to earth." Fried, 60 Tex L Rev at 57 (cited in note 62). 
analysis of legal issues. ${ }^{998}$ Theory-oriented philosophy has limited application to the law and cannot account for the particularities of human experience. As Hamlet justly noted, "There are more things in heaven and earth Horatio/Then are dream't of in your philosophie. ${ }^{\text {m99 }}$

As a practical enterprise, the law must be sensitive to consequences. While grand theories of justice, fairness, and individual rights might inform a judge's jurisprudence, all of these must still be evaluated in light of the ultimate decision-" consequences are never irrelevant in law." ${ }^{\$ 100}$ Consequences in philosophy, however, do not have the same practical or moral force. What do metaphysics and epistemology have to do with concrete results? Not very much. ${ }^{101}$ While there may be particular philosophies that are consequentialist, such as utilitarianism, the philosophical enterprise is a deontological one that aims at principles, not at ends. ${ }^{102}$ It looks at human goods from a perspective that seeks to transcend the limits of human experience, to articulate, as the Philosophers' Brief did, "fundamental principles of liberty and justice."103

Unlike much of professional philosophy, there cannot be any grand truths in the law because it does not seek to establish an overarching theory-there is no "metanarrative" here. ${ }^{104}$ Cass Sunstein has frequently argued that judges should avoid recourse to high level principles when deciding cases:

Judges ordinarily work with principles of a low level of theoretical ambition. ... [L]ike almost all of us, judges are not trained philosophers. They know that if they try to resolve large philosophical issues, they may blunder badly. In these

Posner, 29 Ariz St L J at 380-81 (cited in note 85). While against Dworkin's philosophical efforts to influence the Court, Judge Posner frequently makes nonlegal references in his own opinions.

William Shakespeare, Hamlet, I v lns 166-67 (Oxford 1964).

${ }^{100}$ Richard Posner, The Problems of Jurisprudence 148 (Harvard 1990). Posner argues that "at some point the outcome that lacks political sense, that represents bad policy, that has distinctly untoward anticipated consequences, may by virtue of that fact not be the outcome required (permitted?) by law." Id at 145.

${ }^{101}$ See Immanuel Kant, Grounding for the Metaphysics of Morals $\S 1$ at lns 399-400 (Hackett 1981) (J.W. Ellington trans) ("The moral worth depends, therefore, not on the realization of the object of the action, but merely on the principle of volition according to which ... the action has been done.").

${ }^{102}$ Even utilitarians must make a principled value choice that individuals ought to maximize utility or that the political system should maximize overall social utility.

${ }^{108} 1996$ WL 708956 at *2 (emphasis added).

${ }^{104}$ In this regard, the traditionalism of the law might be seen as very postmodern, since it possesses what Jean-François Lyotard considered the defining feature of the postmodern: "an incredulity toward metanarratives." Jean-François Lyotard, The Postmodern Condition xxiv (Minnesota 1984) (Bennington and Massumi trans). 
circumstances judges try, to the extent that they can, to bracket large-scale issues of the good and the right.... This point helps explain the legal culture's distrust of philosophical abstractions. ${ }^{105}$

Large-scale philosophical questions do not belong in an institution primarily concerned with reaching practical results about particularized disputes. Thus, in a democracy, it makes sense for courts to bracket larger issues of the "good" in favor of more concrete decisions.

\section{B. Structural and Institutional Limits}

Courts and judges operate within a political structure established to promote democratic accountability and the separation of powers. The Supreme Court has a certain prescribed sphere of influence - to decide a certain class of cases and controversies-and has no legitimate authority to step beyond these boundaries. ${ }^{106}$ While history has followed Chief Justice John Marshall's famous statement that "[i]t is emphatically the province and duty of the judicial department to say what the law is, ${ }^{107}$ there is still a strong presumption against judicial policy making. Such authority properly resides in the legislature, the politically accountable branch of government. ${ }^{108}$ A judge might have specific policy preferences regarding the good and the just, but it is not within his assigned role to make decisions based on these factors. The legislator, however, can reflect his philosophical preferences and prejudices in law making because he is democratically accountable for his decisions. ${ }^{109}$ Thus, it is appropriate that in the past thirteen years Congressional debates and speeches, as recorded in the Congressional Record, has referenced philosophers almost

${ }^{105}$ Sunstein, 29 Ariz St L J at 391-92 (cited in note 44).

${ }^{106}$ US Const, Art III, $\S 2$ ("The judicial Power shall extend to all Cases, in Law and Equity, arising under this Constitution, the Laws of the United States, and Treaties made, or which shall be made, under their Authority ... [and] to Controversies between two or more States;- -between a State and Citizens of another State;-between Citizens of different States ....").

${ }^{107}$ Marbury $v$ Madison, 5 US (1 Cranch) 137, 176 (1803).

${ }^{108}$ Although a strong supporter of judicial review, Marshall later said in discussing the National Bank, "where the law is not prohibited, and is really calculated to effect any of the objects entrusted to the government, to undertake here to inquire into the degree of its necessity, would be to pass the line which circumscribes the judicial department, and to tread on legislative ground." McCulloch $v$ Maryland, 17 US (4 Wheat) 316, 423 (1819).

${ }^{109}$ Fried makes a related point: the discussion of moral rights and philosophical values should be left for individuals engaged in the democratic process. If untrained judges can make philosophical judgments, then so can ordinary citizens, and they should be allowed to do so through the political process. Fried, 60 Tex L Rev at 37-38 (cited in note 62). 
twenty times more frequently than the Court has in its entire history. ${ }^{110}$

Traditional methods of legal reasoning also restrain judges. Judges do not apply previous legal rules and decisions scientifically, but rather are constrained by a whole network of institutional factors and considerations. In discussing the Courts opinion in Brown $v$ Board of Education, ${ }^{111}$ Owen Fiss, a strong proponent of the autonomy of legal reasoning, argues that the Justices

consider the role of the state, and the place of public education in particular, in the life of the nation and weigh the evidence developed at trial on the impact of segregative practices. ... In sum, the justices are disciplined in the exercise of their power. They are caught in a network of so-called "disciplining rules" which, like a grammar, define and constitute the practice of judging and are rendered authoritative by the interpretive community of which the justices are part. ${ }^{112}$

Although Brown arguably went against the historical understanding of the Fourteenth Amendment, most commentators, including conservative ones, consider the case to be rightly decided because it responded to changes in social and political realities. ${ }^{113}$ The Court faces limits and checks on its power by what has been decided in earlier cases and by what is within socially and politically acceptable reasoning. Also, without the power to execute the law, the Court must confine itself to hearing justiciable cases or controversies in order to protect its political capital. ${ }^{114}$ The judge

${ }^{110}$ See Part III.B.

"'1 347 US 483 (1954).

${ }^{112}$ Fiss, 72 Cornell L Rev at 11 (ci+ed in note 60). See also Owen M. Fiss, Objectivity and Interpretation, 34 Stan L Rev 739, 762-63 (1982) (arguing that objective boundaries limit the possible legal interpretations of a text).

${ }^{113}$ See, for example, Michael W. McConnell, Originalism and the Desegregation Decisions, $81 \mathrm{Va}$ L Rev 947, $952 \mathrm{n} 16$ (1995) ("Such is the moral authority of Brown that if any particular theory does not produce the conclusion that Brown was correctly decided, the theory is seriously discredited.").

"For example, under the well-established political question doctrine, the Court has declined to hear cases that (1) lack judicially manageable standards and (2) have been constitutionally committed to another branch. See, for example, Nixon v United States, 506 US 224, 237-38 (1993) (holding that the Court could not review the Senate's choice of procedure in impeachment proceedings); Goldwater $v$ Carter, 444 US 996, 1002-03 (1979) (Rehnquist concurring) (asserting that a dispute between the Executive and Legislature over the President's power to terminate a treaty was unreviewable as a political question); Baker $v$ Carr, 369 US 186, 210-17 (1962) (establishing the modern boundaries of the political question doctrine). 
must rely on his particular legal knowledge and expertise-no amount of philosophical expertise can trump this. ${ }^{115}$

The structure of the courts and our historical understanding of the judicial system also limit the judge. He cannot address an issue until it comes before him through the initiative of individuals or government prosecutors. The well-established doctrine of standing prevents parties from trying cases in which there is no injury or in which courts cannot provide an adequate remedy. ${ }^{116}$ Mootness and ripeness ensure that there is an extant, concrete, and well-formed harm for the courts to address. ${ }^{117}$ Also, the Supreme Court has historically refused to issue "advisory opinions," even upon the request of other branches of the government. ${ }^{118}$ These structural and doctrinal safeguards constrain judicial activism.

Moreover, the Court's powerful institutional authority does not translate into intellectual authority. Charles Collier argues that Supreme Court opinions are not philosophical works and do not persuade intellectually. ${ }^{119}$ Judges can rule on the matters be-

${ }^{111}$ When James I asserted that he could remove cases from the law courts and try them personally since he possessed philosophical expertise, Chief Justice Coke responded:

[T] Ke King said, that he thought the law was founded upon reason, and that he and others had reason, as well as the Judges: to which it was answered by me, that true it was, that God had endowed His Majesty with excellent science . . . but His Majesty was not learned in the laws of his realm of England, and causes which concern the life, or inheritance, or goods, or fortunes of his subjects, are not to be decided by natural reason but by the artificial reason and judgment of law, which law is an act which requires long study and experience.

Prohibitions Del Roy, 12 Coke Rep 63, 65, reprinted in 77 Eng Rep 1342, 1343 (KB 1607), cited in Charles M. Yablon, Law and Metaphysics, 96 Yale L J 613, 614 n 4 (1987).

${ }^{116}$ See Lujan $v$ Defenders of Wildlife, 504 US 555, 560-61 (1992) (requiring, for constitutional standing, injury in fact to the plaintiff, causation by the defendant, and redressability).

${ }^{117}$ See Laird $v$ Tatum, 408 US 1, 13-14 (1972) (dismissing a suit for lack of ripeness that alleged unlawful surveillance activity against the army). See generally Note, The Mootness Doctrine in the Supreme Court, 88 Harv L Rev 373 (1974).

${ }^{118}$ In 1793, the justices of the Supreme Court respectfully declined to answer President Washington's questions about American neutrality in the war between England and France, saying "the three departments of the government . . . being in certain respects checks upon each other-and our being judges of a court in the last resort-are considerations which afford strong arguments against the propriety of our extrajudicially deciding the questions alluded to." Richard H. Fallon, Jr., Daniel J. Meltzer, and David L. Shapiro, Hart and Wechsler's The Federal Courts and the Federal System 92-93 (Foundation 4th ed 1996).

${ }^{119}$ Charles W. Collier, The Use and Abuse of Humanistic Theory in Law: Reexamining the Assumptions of Interdisciplinary Legal Scholarship, 41 Duke L J 191, 221 (1991). "The fact that [the justices of the Supreme Court] have . . . institutional authority' simply obscures the fact that they do not have 'intellectual authority.' . . . [T] tional facts make inherently implausible any attempts to attribute grand, philosophical doctrines to the judiciary." Id. 
fore them, but their independent philosophical opinions on justice, sex equality, or free will have no particular weight. The justices draw their status and influence from their institutional position.

Philosophers, on the other hand, have neither political nor institutional authority. All of the elegant and erudite essays in The New York Review of Books can be written and read without much real-world consequence. Dworkin can explain his views on assisted suicide, but unless the Court takes up these ideas and incorporates them into a decision, the article has no legal effect. Nevertheless, works by prominent philosophers have intellectual authority - their ideas have independent persuasive value. But their arguments have none of the institutional limitations placed on courts because philosophers work in a world of relative academic freedom. ${ }^{120}$ This academic world does not speak easily to the courts, which have to consider limits on subject matter, the binding force of precedent, statutory language, and the Constitution.

Thus, where the Court does cite philosophers, the mention is often brief, as a kind of presumptive authority. The constitutional and structural limits placed on judges make it inappropriate for them either to engage in ambitious philosophical abstractions or to use philosophical references as a proxy for such reasoning. The rhetorical ploy of using philosophers in controversial political cases circumvents the institutional limits of the Court and provides a backdoor method for judicial policy making. Although such usage is not yet widespread, it is increasing, which should present cause for concern.

\section{Historical Understanding}

History places one of the strongest institutional limits on judicial reasoning and distinguishes it from philosophy. Judicial decisions within the Anglo-American legal system must incorporate the understanding of previous legal decisions as well as political practices even though federal courts enjoy relative independence from the political forces of democracy. Stare decisis is a well-established principle within our judicial system. It requires judges at least to consider previous judgments and rule in accordance with them unless a new case can be distinguished. Al-

\footnotetext{
${ }^{120}$ In discussing the Philosophers' Brief, Sunstein writes, "the Court should generally be reluctant to invalidate legislation on the basis of abstract philosophical arguments ... because predicted consequences, on which philosophical arguments tend to be silent, matter a great deal to law." Sunstein, 29 Ariz St L J at 390 (cited in note 44).
} 
though so much a part of common law understanding, stare decisis does not fit into any absolute theory of when and how precedents should be used. ${ }^{121}$ As Judge Frank Easterbrook has pointed out, "to have a theory of precedent is to have a theory of the extent to which judges' acts are law. Yet we do not have such a theory. ${ }^{\text {s122 }}$

Thus, stare decisis must, like many other legal principles, rely on cultural and historical understanding for its implementation. Frequently departing from precedent would be a type of judicial activism, but a dogmatic adherence to obsolete and incorrectly decided cases would be a form of judicial irresponsibility. The legal system has a built-in conservatism: each case presents a balancing test of sorts between the decisions of the past and the imminent needs of the present. Chief Justice Rehnquist's restrained opinion in Glucksberg reflects this balance. ${ }^{123}$

Judicial adherence to precedent and the past stands in stark contrast to philosophy. A presumption that previous decisions will be followed provides notice to citizens, and thus allows them to order their lives in a manner consistent with the law. The judge also utilizes old decisions and ideas because they are a part of legal and political history and because conformity with these precedents generates a presumption of legitimacy and provides cultural continuity. Philosophers, on the other hand, study thinkers of the past, but these are generally not seen as binding authority. ${ }^{124}$ Each philosopher can depart from the past in order to discover enduring and eternal truths-earlier works have no special priority. Thus, philosophical unrootedness is inappropriate in judicial decision making, where the past confers notice, stability, and confidence; abstractions often lack legal legitimacy and persuasiveness.

${ }^{121}$ For a position advocating absolute stare decisis in statutory interpretation, in order to preserve Congress's policy-making role, see Lawrence C. Marshall, "Let Congress Do It": The Case for an Absolute Rule of Statutory Stare Decisis, 88 Mich L Rev 177 (1989). Compare William N. Eskridge, Jr., The Case of the Amorous Defendant: Criticizing Absolute Stare Decisis for Statutory Cases, 88 Mich L Rev 2450 (1990).

${ }^{12}$ Frank H. Easterbrook, Stability and Reliability in Judicial Decisions, 73 Cornell L Rev 422, 422 (1988).

${ }^{123}$ See text accompanying notes 39-46.

${ }^{124}$ See Anthony T. Kronman, Precedent and Tradition, 99 Yale L J 1029, 1032 (1990), for an excellent discussion of the use of precedent as a defining characteristic of the law:

[W] herever there exists a set of practices and institutions that we believe are entitled to the name of law, the rule of precedent will be at work, influencing, to one degree or another, the conduct of those responsible for administering the practices and institutions in question. By contrast, the rule of precedent has no place in philosophy and is indeed antithetical to its governing spirit. 
Perhaps, however, extra-legal sources can help judges to determine when a departure from past practice might be necessary - philosophy might be a vehicle for legal change. But legal reasoning includes its own processes for change, and reliance on the past does not bind judges to outmoded principles when social and political understandings have evolved. Thoughtful traditionalists, like Edmund Burke, Michael Oakeshott, ${ }^{125}$ and Anthony Kronman, recognize the possibility and the necessity for change within a tradition or convention. Kronman, arguing against criticisms from Judge Posner, said:

I do not think of conventionalism as blind adherence to going practices; every convention worth its salt, every meaningful convention, has an open-texturedness which not only allows but actually requires its development over time. That is the mark of a great tradition, and I think it is the mark of the tradition of the law. ${ }^{126}$

The Anglo-American legal tradition has been heavily influenced by the conservatism of writers such as Burke, who focused on practical wisdom and experience, and who were deeply suspicious of the rationalist philosophers generating revolution and rebellion across the English Channel. ${ }^{127}$ For Burke, there was prudence in following what had come before and accepting change only in slow, incremental, and considered forms. In modern legal scholarship, neotraditionalists such as Kronman have embraced Burkean prudentialism as a response to the critical legal studies movement's politicization of the law. Neotraditionalism, according to Judge Posner, identifies with four main principles. The first is antireductionism, the idea that the law cannot be reduced to another discipline such as philosophy, economics, or politics. The second is that law is a middle between the extreme ideas of law as an art and law as science. The third is that law is a form of

${ }^{125}$ Oakeshott writes, "A tradition of behaviour is not a fixed and inflexible manner of doing things; it is a flow of sympathy," and "It is steady because, though it moves, it is never wholly in motion; and though it is tranquil, it is never wholly at rest." Michael Joseph Oakeshott, Political Education, in Michael Joseph Oakeshott, Rationalism in Politics 126, 128 (BasicBooks 1962).

${ }^{123}$ Discussion: Jurisprudential Responses to Legal Realism, 73 Cornell L Rev 341, 347 (1988), quoting Anthony Kronman during a discussion of his article, Jurisprudential Responses to Legal Realism, 73 Cornell L Rev 335 (1988), at The Federalist Society Sixth Annual Symposium on Law and Public Policy: The Crisis in Legal Theory and the Revival of Classical Jurisprudence.

${ }^{127}$ Burke said that of the men elected into the Tiers Etat, there were some of rank and talent, "but of any practical experience in the state, not one man was to be found. The best were only men of theory." Burke, Reflections on the Revolution at 35 (emphasis added) (cited in note 95). 
Aristotelian practical reason, involving deliberation and prudential, incremental change. The final principle is the idea of interpretive communities, ${ }^{128}$ that a legal text acquires meaning partially against the community of lawyers to which it is addressed. ${ }^{129}$ This conservative approach distinguishes the law from the goals and methods of professional philosophy.

Although the neotraditionalist characterization of the law accords with the Anglo-American tradition, the neotraditionalists take these premises and conclude that the law should be an autonomous discipline, relying primarily on its own history and cases for understanding. This conclusion, however, is not sustainable in today's world where modern disciplines already have affected and continue to influence analysis and understanding of the law. Work in economics, social science, and philosophy has changed the understanding and practice of law. Ironically, many of the neotraditionalists criticize the interdisciplinary focus in law from their own backgrounds in philosophy and social theory. ${ }^{130}$ This Comment suffers from a similar dilemma-it tries to show that philosophy and judicial decision making are inherently different enterprises, but resorts to the insights of philosophers from Aristotle to Nietzsche to support this proposition. Law's institutional authority and structural limits will always make it somewhat autonomous, but legal understanding occurs against a cultural and historical background, and the insights provided by other academic disciplines will inevitably color and affect these cultural understandings.

The use of precedent and history in the law is customarily justified for utilitarian or rule of law reasons. It is pragmatic to follow earlier decisions because this both promotes judicial economy and generates consistency. Nietzsche said that man became interesting when he developed a memory. ${ }^{131}$ As Kronman, a more contemporary defender of this view, writes:

The past is not something that we, as already constituted human beings, choose for one reason or another to respect; rather, it is such respect that establishes our humanity in

${ }^{128}$ See Stanley Fish, Is There a Text in This Class? The Authority of Interpretive Communities (Harvard 1980); Stanley Fish, Doing What Comes Naturally: Change, Rhetoric, and the Practice of Theory in Literary and Legal Studies (Duke 1989).

${ }^{129}$ Posner, Jurisprudence at 434-37 (cited in note 100).

${ }^{130}$ Anthony Kronman, for example, has a Ph.D. in philosophy and has written articles employing economic analysis, as well as a book that relies heavily on philosophers like Aristotle and Kant. See Kronman, The Lost Lawyer (cited in note 57).

${ }^{131}$ Friedrich Nietzsche, On the Genealogy of Morals 57-60 (Vintage 1989) (Walter Kaufmann trans) (discussing how the development of memory makes men trustworthy and solid). 
the first place. We must, if we are to be human beings at all, adopt toward the past the custodial attitude Burke recommends. That attitude is itself constitutive of our membership in the uniquely human world of culture; it is what makes us cultural beings, as opposed to animals or thinkers. ${ }^{132}$

Philosophy, in contrast, is opposed to such a memory; it does not want to be bound by the prejudices of the particular. Philosophy hopes to soar in order to find universal truths, not local understandings of culture or tradition-these are better left for the historian, the statesman, or the judge. Philosophy's value comes from its ability to stand apart from what exists, to cast the light of reason into the dark cave. But the law cannot stand at such a critical distance-it is an institution very much of this world, tied to human particularity in all of its confused complexity.

\section{CONCLUSION}

In Glucksberg, Chief Justice Rehnquist rejected the abstract claims of the Philosophers' Brief. Supreme Court opinions have with increasing frequency, however, used philosophers to justify positions on controversial political issues. While explicit policy making by the Court is rare, the Court sometimes uses nonlegal sources such as philosophy to expand the scope of its decisions. This backdoor means of policy making ultimately lacks legitimacy and legal persuasiveness. For a number of institutional, structural, and historical reasons, policy judgments should not be masked by philosophical references. 


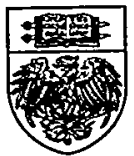

